\title{
ADDITION OF BOILER CHARCOAL WASTE TO COMPOST FOR USE AS SUBSTRATE FOR VEGETABLE SEEDLINGS
}

\author{
Higor E. F. Lorin ${ }^{1 *}$, Mônica S. S. de M. Costa ${ }^{1}$, Maico Chiarelotto ${ }^{1}$, Francielly T. dos Santos ${ }^{1}$, \\ Luiz A. de M. Costa ${ }^{1}$
}

${ }^{1 *}$ Corresponding author. Research Group on Water Resources and Environmental Sanitation, Western Paraná State University UNIOESTE/ Cascavel - PR, Brazil.

E-mail: higorf@hotmail.com | ORCID ID: https://orcid.org/0000-0002-5659-1407

\begin{abstract}
KEYWORDS
electrical conductivity, circular economy, easiness of removal of clod from tray, seedling quality index, salinity.
\end{abstract}

\begin{abstract}
The recovery of waste from the broiler production chain (BPC) is consistent with the principles of a circular economy. Besides turning waste into organic compost, its use as substrate for the production of vegetable seedlings further increases its economic value. However, it is necessary to adapt its characteristics to enable its use as substrate. To this end, the addition of boiler remnant charcoal wastes $(\mathrm{BCW})$, another type of waste generated in the BPC, to the organic compost resulting from the composting of BPC waste with different bulking agents (BAs) was studied. The addition of BCW to agro-industrial compost reduced the electrical conductivity (EC) of substrates. Multiple linear regression showed that, of the 13 variables (physical, chemical and physicochemical) studied, three (EC, $\mathrm{pH}$ and $\mathrm{N}$ content) are sufficient to explain the seedling quality index (SQI). Simple nonlinear regression showed that, in order to achieve higher SQIs and easier removal of clod from tray, an additional $30 \%$ in weight of $\mathrm{BCW}$ is required for compost, using urban tree pruning, wood sawdust and sugarcane bagasse BAs. The use of cotton and Napier grass waste as BAs is not recommended for BPC waste mixtures, as they cause a large increase in substrate EC.
\end{abstract}

\section{INTRODUCTION}

The use of waste generated at different stages of the broiler production chain, as in other industries, is connected to the principles of circular economy. According to Stahel (2016), a "circular economy" would turn goods that are at the end of their service life into resources for others, closing loops in industrial ecosystems and minimizing waste. It would change economic logic because it replaces production with sufficiency: reuse what you can, recycle what cannot be reused, repair what is broken, remanufacture what cannot be repaired.

The recovery of agro-industrial waste from the broiler production chain (BPC) through composting has been reported in the national (Bernardi et al., 2018) and international literature (Costa et al., 2017). The organic compound produced, in turn, can be used as a soil conditioner for crops or as substrate for the production of vegetable seedlings. There are advantages and disadvantages in marketing both products. As a substrate for seedling production, the organic compound can reach a more attractive market value than organic fertilizers. On the other hand, its physical and chemical properties have to be more specific to achieve the expected results in the production of quality seedlings. Among these properties, electrical conductivity (EC), or salinity, is the characteristic that most affects the development of seedlings (Santos et al., 2015; Moraes et al., 2018), requiring the addition of inert materials such as rice hulls, vermiculite, perlite and sand to the organic compound to decrease salt concentration and thus enable its use as a substrate (Bilderback et al., 2005).

Another type of BPC waste that can contribute to the circular economy of this sector is agro-industrial boiler remnant charcoal wastes $(\mathrm{BCW})$. This waste is generated by the incomplete burning of wood used in furnaces (Eucalyptus spp.) for the production of thermal energy. $\mathrm{BCW}$ does not deposit with firewood ashes, because it is aspirated from agro-industrial furnaces by multi-cyclones, having medium to fine grain size (Costa et al., 2017).

Currently, $\mathrm{BCW}$ joins other wastes generated in the $\mathrm{BPC}$ and is sent to specialized plants to undergo a

${ }^{1}$ Grupo de Pesquisa em Recursos Hídricos e Saneamento Ambiental - RHESA, Universidade Estadual do Oeste do Paraná - UNIOESTE/

Cascavel - PR, Brasil.

Received in: 12-14-2018

Accepted in: 9-23-2019 
composting process. The recovery of $\mathrm{BCW}$ to be used as a component in substrates for seedling production can contribute to improve the characteristics of organic compost and enhance BPC waste, generating a new product with higher market value: horticultural substrates. In addition, since it is a biomass subject to pyrolysis at temperatures that can reach between $300^{\circ} \mathrm{C}$ and $650^{\circ} \mathrm{C}, \mathrm{BCW}$ may have similar properties to biochar, a material widely studied as a substrate component for seedlings (Méndez et al. 2015; Nieto et al., 2016; Kaudal et al., 2016). However, most references in which biochar is used as a substrate for seedling production are intended to evaluate its effect as a substitute for peat, a non-renewable natural resource widely used due to its excellent combination of chemical, physicochemical and physical properties, such as low $\mathrm{pH}$, high CEC (Cation Exchange Capacity) and adequate porosity (Nieto et al., 2016).

When agro-industrial organic compost is used as substrate for seedling production, EC may be a limiting factor due to the high nutrient concentrations. Moreover, the controlled (indoor) conditions of the composting process promote the degradation of the organic material by microorganisms and considerably reduce windrow mass, increasing the concentration of salts in the organic compost. The more easily degradable the main carbon source of the compost mass, the higher the $\mathrm{EC}$ of the final compost (Costa et al., 2017).
Thus, the viability of using high EC organic compost as substrate for seedling production depends on the addition of inert materials to act as salinity diluents. Therefore, the objective of this work is to evaluate the use of different types of organic compost from the composting of agroindustrial BPC waste as substrates for lettuce seedlings production, through the addition of $\mathrm{BCW}$.

\section{MATERIAL AND METHODS}

\section{Compost provenance and Substrate preparation}

Five types of organic compost were obtained from five BPC waste composting processes, plus a bulking agent (BA). Each BA was used exclusively in each windrow, and received different amounts of BPC waste in order to adjust the carbon nitrogen ratio to around thirty $(\mathrm{C}: \mathrm{N} \approx 30)$. Because of that, compost windrows ranged from 500 to 710 $\mathrm{kg}$ in terms of fresh matter, 270 to $330 \mathrm{~kg}$ in terms of dry matter, and were 2 to $7 \mathrm{~m}^{3}$ in volume, depending on the BA used. The BA used and the percentages of waste added to each of the five windrows (A, P, S, B and N) are shown in Table 1 . The entire composting process was conducted in an open compost yard, with cover and concrete floors. A detailed description of the composting process to obtain this composts is given by Costa et al. (2017). After obtaining the organic compost, it was ground in a waste crusher and sieved in a $5 \mathrm{~mm}$ mesh sieve.

TABLE 1. Characteristics and proportions of the wastes used in the five composting piles to obtain the organic composts.

\begin{tabular}{|c|c|c|c|c|c|}
\hline Windrows & $\mathbf{A}$ & $\mathbf{P}$ & $\mathbf{S}$ & B & $\mathbf{N}$ \\
\hline Bulking agent (\%) & 51 & 50 & 50 & 50 & 50 \\
\hline Sausage casings $(\%)$ & 33 & 20 & 14 & 13 & 30 \\
\hline Reproductive poultry litter (\%) & 8 & 12 & 8 & 10 & 8 \\
\hline Hatchery waste (\%) & 4 & 12 & 14 & 13 & 8 \\
\hline Flotation sludge (\%) & 4 & 6 & 14 & 14 & 4 \\
\hline Initial volume $\left(\mathrm{m}^{3}\right)$ & 3.9 & 3.8 & 1.9 & 7.0 & 3.2 \\
\hline Initial bulk density $\left(\mathrm{g} . \mathrm{cm}^{-3}\right)$ & 0.13 & 0.14 & 0.28 & 0.08 & 0.22 \\
\hline
\end{tabular}

Bulking agent A: Cotton waste; P: urban tree pruning; S: Wood Sawdust; B: Sugarcane bagasse; N: Napier grass. Data expressed in percentage of dry matter.

For the preparation of the substrates, each of the five types of compost obtained (A, P, S, B and N) in the composting process was mixed with five doses $(0,15,30,45$ and $60 \%)$ in dry matter of remnant charcoal waste from agro-industrial boilers (BCW), totaling 25 substrates. The main chemical, physical and physicochemical characteristics of BCW are presented in Table 2.

TABLE 2. Characterization of the boiler remnant charcoal waste used as a component in the preparation of substrates.

\begin{tabular}{|c|c|c|c|c|c|c|c|c|c|c|c|}
\hline & pH & $\begin{array}{c}\mathbf{E C} \\
\left(\mathrm{dS} . \mathrm{m}^{-1}\right)\end{array}$ & $\begin{array}{c}\mathrm{C} \\
(\%)\end{array}$ & $\begin{array}{c}\mathbf{N} \\
(\%)\end{array}$ & $\begin{array}{c}\mathbf{P} \\
\left(\mathrm{g} \cdot \mathrm{kg}^{-1}\right)\end{array}$ & $\begin{array}{c}\mathbf{K} \\
\left(\mathrm{g} \cdot \mathrm{kg}^{-1}\right)\end{array}$ & $C: N$ & $\begin{array}{l}\text { HLIF } \\
\text { index }\end{array}$ & $\begin{array}{c}\text { BD } \\
\left(\mathrm{g} . \mathrm{cm}^{-3}\right)\end{array}$ & $\begin{array}{c}\text { WHP } \\
(\%)\end{array}$ & PS \\
\hline BCW & 10.3 & 0.8 & 28.3 & 0.2 & 0.3 & 5.7 & 153 & 325 & 0.13 & 386.5 & $<2 \mathrm{~mm}$ \\
\hline
\end{tabular}

BCW: boiler remnant charcoal waste; EC: Electrical conductivity; N: Nitrogen; P: Total Phosphorus; K: Potassium; C:N: Carbon to nitrogen ratio; HLIF: humification index (Laser Induced Fluorescence); BD: Bulk density; WHP: water-holding porosity; PS: Particle size. 


\section{Conducting the Experiment}

The experiment was conducted in a greenhouse with a $30 \%$ Aluminet ${ }^{\circledR}$ shade cloth covering. The 25 prepared substrates and the commercial substrate (CS) were placed in 200 cell expanded polystyrene trays. Considering four repetitions of each of the 25 substrates, plus 20 repetitions of the commercial substrate Tropstrato HT®, there were a total of 120 experimental plots. Each plot was randomized and consisted of 30 tray cells. Pelleted Lucy Brown lettuce seeds treated with $0.22 \%$ Thiram were used. Sowing was performed in trays with one seed per cell covered with the respective substrates. The daily watering of trays was performed manually using a watering can for vegetables. Trays were rotated inside the greenhouse every two days to avoid uneven light incidence. During the first 16 days after sowing, the number of emerged seeds was counted daily. After 30 days of cultivation, phytometric assessments were performed on 20 random plants of each substrate. For the assessment of clod properties, eight seedlings from each substrate were randomly chosen.

\section{Analytical Methods}

Analytical methods were the same for all substrates, including prepared mixtures, commercial substrate (CS) and $\mathrm{BCW}$. The values of $\mathrm{pH}$ and $\mathrm{EC}$ were determined through an aqueous extract of the substrate $(1: 5 \mathrm{w} / \mathrm{v})$ (Embrapa, 2009). Organic matter (OM) content was determined through volatile solids, after calcination in a muffle furnace at $550^{\circ} \mathrm{C}$ (Carmo \& Silva, 2012). Nitrogen (N) content was determined through a Kjeldahl distiller (Malavolta et al., 1997). Phosphorus (P) and potassium (K) levels were determined after nitro-perchloric digestion (3:1). P reading was performed using a spectrophotometer (Malavolta et al., 1997) and $\mathrm{K}$ reading was conducted using a flame photometer (Embrapa, 2009). Laser Induced Fluorescence (LIF) was employed according to the methodology proposed by Milori et al. (2006). The determination of the humification index (HLIF) based on LIF spectroscopy was founded on the ratio between the area of the fluorescence emission spectrum (440-800 nm) and the total organic carbon concentration. The volumetric ring method, described by Tian et al. (2012), was used to determine bulk density (BD), total porosity (TP), aeration porosity (AP) and water-holding porosity (WHP) using the formulas: $\mathrm{BD}\left(\mathrm{g} . \mathrm{cm}^{-3}\right)=(\mathrm{W} 4-\mathrm{W} 0) / \mathrm{V} ; \mathrm{TP}(\%)=(\mathrm{W} 2-\mathrm{W} 4)$ $/ \mathrm{V} \times 100 ; \mathrm{AP}(\%)=(\mathrm{W} 2-\mathrm{W} 3) / \mathrm{V} \times 100 ;$ and $\mathrm{WHP}(\%)=\mathrm{TP}$ - AP; where W0: set mass (ring + rubber band + cleaning cloth); W1: set mass + dry sample; W2: set mass + saturated sample; W3: drained set mass; W4: dry set mass at $65^{\circ} \mathrm{C}$; $\mathrm{V}$ : ring volume. For total water-holding capacity (TWHC), the formula TWHC $\left(\mathrm{mL} \cdot \mathrm{L}^{-1}\right)=((\mathrm{W} 3-\mathrm{W} 4) /(\mathrm{W} 4-$ $\mathrm{W} 0)) /(1 / \mathrm{BD} / 1000)$ was used.

Emergence percentage (E) and emergence speed index (ESI) were determined according to Maguire et al. (1962). In order to determine E, the percentage of seeds emerged by the 15 th day was calculated. During this period, ESI and mean emergence time (MET) were also determined, which were calculated according to the formulas: $\mathrm{ESI}=\Sigma(\mathrm{Pi} / \mathrm{Di})$ and $\mathrm{MET}=\Sigma(\mathrm{Si} * \mathrm{Di}) / \mathrm{Nt}$; where: Si: number of seedlings emerged on the ith day of counting (not accumulated); Di: number of days in which seedlings emerged on the ith day; $\mathrm{Nt}$ : total number of seedlings emerged during the assessment period.
The phytometric parameters assessed were stem diameter (SD), shoot height (SH), root dry mass (RDM) and shoot dry mass (SDM). The Seedling Quality Index (SQI) was calculated according to Dickson et al. (1960), using the formula $\mathrm{SQI}=(\mathrm{SDM}+\mathrm{RDM}) /(\mathrm{SDM} / \mathrm{RDM})+(\mathrm{SH} / \mathrm{SD}))$. Total chlorophyll was determined by the sum of chlorophylls a $(633 \mathrm{~nm})$ and $\mathrm{b}(645 \mathrm{~nm})$, determined by a spectrophotometer (Arnon, 1949).

Clod quality properties after cultivation were determined by the easiness of removal of clod from tray (ERT) and clod stability (CSt), according to the adapted methodology for seedlings grown in tubes (Kratz \& Wendling, 2013). ERT was scored from 0 to 10 , based on the removal of seedling with clod from tray, where zero corresponded to maximum difficulty and seedling disruption, and ten to maximum easiness and clod integrity. As for CE, seedlings removed from tray were subjected to a one-meter-high free fall, which was scored from 0 to 10 , where zero corresponded to a completely destroyed clod and ten to a totally intact one.

\section{Statistical Analyses}

Principal Component Analysis (PCA) was used to summarize and interpret the relationships between the effect of substrates (25 prepared $+\mathrm{CS}$ ) on seedling development and quality, as well as on clod stability properties (7 parameters analyzed). Accumulated explanation percentages above $70 \%$ were used as selection criteria of components. In order to estimate the SQI explanation model, multiple linear regression (MLR) was used, categorizing SQI as a response (dependent) variable to the chemical, physicochemical and physical characteristics (13 explanatory variables) of the prepared substrates. In order to select the best MLR equation, the Best Subsets Regression tool was used. The combination of explanatory variables with the highest $\mathrm{R}^{2}$, lowest standard error and $\mathrm{Cp}$ closest to the number of parameters was chosen. In order to validate the model, the assumptions of error randomness $(\varepsilon) ; \varepsilon$ zero mean; $\varepsilon$ homoscedasticity (Goldfeld-Quandt test); $\varepsilon$ normality (Anderson-Darling); absence of serial autocorrelation (Durbin-Watson); absence of $\mathrm{Xi}$ measurement error; and absence of multicollinearity (variance inflation factor-VIF) were checked. For the detection of influential points, the following estimates were used: hii Element (leverage), Cook's Distance (Di) and Modified Cook's (DFit). Simple nonlinear regression (SNLR) was used to predict the ideal percentage of BCW required to achieve the maximum theoretical values of SQI and ERT.

\section{RESULTS AND DISCUSSION}

\section{Effect of addition of boiler remnant charcoal waste (BCW) to organic compost}

In general, the addition of increasing doses of $\mathrm{BCW}$ to the organic compost generated by the composting of BPC agro-industrial waste decreased OM, N, P, EC contents and the HLIF index, while increasing substrate $\mathrm{pH}$ (Table 3). This was due to the low C, N, P, EC and HLIF content of $\mathrm{BCW}$ (Table 2), as well as its alkaline character, which contributed, respectively, to a decrease in these variables and an increase in the $\mathrm{pH}$ of the prepared substrates. 
TABLE 3. Percentage of boiler remnant charcoal waste $(\mathrm{BCW})$ added to substrates and chemical and physicochemical properties of substrates.

\begin{tabular}{|c|c|c|c|c|c|c|c|c|}
\hline Substrates & $\begin{array}{c}\text { BCW } \\
(\%)\end{array}$ & $\begin{array}{l}\text { OM } \\
(\%)\end{array}$ & $\begin{array}{l}\mathrm{N} \\
(\%)\end{array}$ & $\begin{array}{l}\mathrm{P} \\
(\%)\end{array}$ & $\begin{array}{c}\mathrm{K} \\
\left(\mathrm{g} \cdot \mathrm{kg}^{-1}\right)\end{array}$ & $\begin{array}{c}\mathrm{EC} \\
\left(\mathrm{dS} . \mathrm{m}^{-1}\right)\end{array}$ & $\mathrm{pH}$ & \multirow{2}{*}{$\begin{array}{l}\text { HLIF } \\
\text { index }\end{array}$} \\
\hline IS $^{g}$ & & $>80$ & & & $0,15-0,25$ & $0,75-2,0$ & $5,3-6,5$ & \\
\hline A0 & 0 & $58 \mathrm{a}$ & $3.5 \mathrm{a}$ & $3.4 \mathrm{a}$ & $13 \mathrm{a}$ & $18.3 \mathrm{a}$ & $7.4 \mathrm{~d}$ & $1149 \mathrm{a}$ \\
\hline A15 & 15 & $55 \mathrm{~b}$ & $2.9 \mathrm{~b}$ & $3.0 \mathrm{~b}$ & $12 a b$ & $15.5 \mathrm{~b}$ & $7.8 \mathrm{c}$ & $767 \mathrm{~b}$ \\
\hline A30 & 30 & $55 \mathrm{~b}$ & $2.5 \mathrm{c}$ & $2.6 \mathrm{c}$ & $12 \mathrm{ab}$ & $13.2 \mathrm{c}$ & $7.8 \mathrm{c}$ & $516 \mathrm{c}$ \\
\hline A45 & 45 & $54 \mathrm{bc}$ & $2.0 \mathrm{~d}$ & $2.3 \mathrm{~d}$ & $11 \mathrm{bc}$ & $7.9 \mathrm{~d}$ & $8.2 \mathrm{~b}$ & $407 \mathrm{~d}$ \\
\hline A60 & 60 & $54 \mathrm{c}$ & $1.4 \mathrm{e}$ & $1.8 \mathrm{e}$ & $10 \mathrm{c}$ & $6.6 \mathrm{e}$ & $8.6 \mathrm{a}$ & $355 \mathrm{~d}$ \\
\hline $\mathrm{P} 0$ & 0 & $65 \mathrm{a}$ & $2.5 \mathrm{a}$ & $2.7 \mathrm{a}$ & $6.9^{\mathrm{ns}}$ & $6.3 \mathrm{a}$ & $7.6 \mathrm{c}$ & $1647 \mathrm{a}$ \\
\hline P15 & 15 & $59 \mathrm{ab}$ & $2.3 \mathrm{~b}$ & $2.5 \mathrm{~b}$ & $7.3^{\mathrm{ns}}$ & $5.8 \mathrm{a}$ & $7.6 \mathrm{c}$ & $1054 \mathrm{~b}$ \\
\hline P30 & 30 & $59 a b$ & $1.8 \mathrm{c}$ & $2.4 \mathrm{~b}$ & $7.2^{\mathrm{ns}}$ & $4.5 \mathrm{~b}$ & $8.2 \mathrm{~b}$ & $591 \mathrm{c}$ \\
\hline P45 & 45 & $58 \mathrm{~b}$ & $1.2 \mathrm{~d}$ & $2.0 \mathrm{c}$ & $7.6^{\mathrm{ns}}$ & $3.8 \mathrm{bc}$ & $8.8 \mathrm{a}$ & $414 \mathrm{~d}$ \\
\hline P60 & 60 & $49 c$ & $1.2 \mathrm{~d}$ & $1.7 \mathrm{~d}$ & $7.4^{\mathrm{ns}}$ & $3.4 \mathrm{c}$ & $8.9 \mathrm{a}$ & $382 \mathrm{~d}$ \\
\hline S0 & 0 & $54 \mathrm{a}$ & $1.6 \mathrm{a}$ & $3.0 \mathrm{a}$ & $3.9 \mathrm{~d}$ & $5.4 \mathrm{a}$ & $7.3 \mathrm{e}$ & $2960 \mathrm{a}$ \\
\hline S15 & 15 & $50 a b$ & $1.4 \mathrm{~b}$ & $2.6 \mathrm{~b}$ & $4.6 \mathrm{c}$ & $5.0 \mathrm{~b}$ & $7.4 \mathrm{~d}$ & $1361 \mathrm{~b}$ \\
\hline $\mathrm{S} 30$ & 30 & $48 \mathrm{bc}$ & $1.2 \mathrm{c}$ & $2.3 \mathrm{c}$ & $5.6 \mathrm{~b}$ & $3.7 \mathrm{c}$ & $8.0 \mathrm{c}$ & $839 c$ \\
\hline S45 & 45 & $46 \mathrm{bc}$ & $1.1 \mathrm{c}$ & $2.0 \mathrm{c}$ & $5.9 \mathrm{ab}$ & $3.2 \mathrm{~d}$ & $8.4 \mathrm{~b}$ & $526 \mathrm{~d}$ \\
\hline S60 & 60 & $43 c$ & $0.8 \mathrm{~d}$ & $1.6 \mathrm{~d}$ & $6.2 \mathrm{a}$ & $2.6 \mathrm{e}$ & $8.7 \mathrm{a}$ & $474 \mathrm{~d}$ \\
\hline B0 & 0 & $53 \mathrm{a}$ & $1.9 \mathrm{a}$ & $3.0 \mathrm{a}$ & $5.4 \mathrm{c}$ & $10.4 \mathrm{a}$ & $6.9 \mathrm{~d}$ & $1872 \mathrm{a}$ \\
\hline B15 & 15 & $47 \mathrm{~b}$ & $1.8 \mathrm{ab}$ & $2.7 \mathrm{~b}$ & $5.7 \mathrm{bc}$ & $8.5 \mathrm{~b}$ & $6.9 \mathrm{~d}$ & $1096 \mathrm{~b}$ \\
\hline B30 & 30 & $47 \mathrm{~b}$ & $1.8 \mathrm{~b}$ & $2.8 \mathrm{~b}$ & $6.1 \mathrm{~b}$ & $6.8 \mathrm{bc}$ & $7.3 \mathrm{c}$ & $826 c$ \\
\hline B45 & 45 & $45 \mathrm{~b}$ & $1.5 \mathrm{c}$ & $2.1 \mathrm{c}$ & $6.8 \mathrm{a}$ & $5.7 \mathrm{c}$ & $7.7 \mathrm{~b}$ & $723 \mathrm{~d}$ \\
\hline B60 & 60 & $46 \mathrm{~b}$ & $1.2 \mathrm{~d}$ & $1.7 \mathrm{c}$ & $7.4 \mathrm{a}$ & $5.1 \mathrm{c}$ & $8.2 \mathrm{a}$ & $463 \mathrm{e}$ \\
\hline N0 & 0 & $66 \mathrm{a}$ & $2.6 \mathrm{a}$ & $2.3 \mathrm{a}$ & $11 \mathrm{a}$ & $11.7 \mathrm{a}$ & $7.6 \mathrm{c}$ & $1071 \mathrm{a}$ \\
\hline N15 & 15 & $62 \mathrm{a}$ & $2.1 \mathrm{~b}$ & $2.3 \mathrm{a}$ & $10 \mathrm{~b}$ & $9.8 \mathrm{ab}$ & $8.4 \mathrm{~b}$ & $794 b$ \\
\hline N30 & 30 & $56 \mathrm{~b}$ & $1.7 \mathrm{c}$ & $2.2 \mathrm{ab}$ & $9.7 b$ & $8.4 \mathrm{bc}$ & $8.3 \mathrm{~b}$ & $623 \mathrm{c}$ \\
\hline N45 & 45 & $50 \mathrm{c}$ & $1.5 \mathrm{c}$ & $1.8 \mathrm{~b}$ & $9.8 \mathrm{~b}$ & $6.7 \mathrm{~cd}$ & $8.7 \mathrm{a}$ & $493 \mathrm{~d}$ \\
\hline N60 & 60 & $49 \mathrm{c}$ & $1.2 \mathrm{~d}$ & $1.2 \mathrm{c}$ & $9.6 \mathrm{~b}$ & $5.5 \mathrm{~d}$ & $8.9 \mathrm{a}$ & $565 \mathrm{~cd}$ \\
\hline $\mathrm{CS}$ & 0 & 49 & 0.52 & 0.23 & 1.8 & 1.0 & 6.3 & - \\
\hline
\end{tabular}

IS: Ideal Substrate, ${ }^{g}$ Optimum or acceptable values for an ideal substrate according to Abad et al. (2004); BCW: boiler remnant charcoal waste; OM: Organic matter; N: Nitrogen; P: Total Phosphorus; K: Potassium; EC: Electrical conductivity; HLIF: humification index; CS: commercial substrate. Equal lowercase letters show no significant minimum difference (LSD) by the F test ( $\alpha: 5 \%)$ among the BCW doses added in each agro-industrial compost.

All substrates presented OM levels below the ideal $(>80 \%)$, including the substrates that did not receive $\mathrm{BCW}$ doses (A0, P0, S0, B0 and N0) and the commercial substrate. In an inventory of organic waste for use as substrates performed by Abad et al. (2001), it was found that almost half $(46 \%)$ of the 63 organic materials studied presented suboptimal OM levels. OM levels below the recommended value $(>80 \%)$ in composted substrates are expected, due to the microbiological degradation of organic fractions and consequent release of $\mathrm{C}$ as $\mathrm{CO}_{2}$ (Costa et al., 2016, 2017; Lorin et al., 2016). As a result, a concentration of macro and micronutrients can be observed (Costa et al.,2017; Gavilanes-Terán et al., 2017) (Table 3).

The significant decrease $(\mathrm{p}<0.05)$ in substrate OM, $\mathrm{N}, \mathrm{P}$ and $\mathrm{EC}$ levels due to the increasing addition of $\mathrm{BCW}$ doses $(15,30,45$ and $60 \%)$ showed that this component acts as a diluent for agro-industrial compost. Pearson's linear correlation showed that $\mathrm{BCW}$ percentage and $\mathrm{EC}$ are strong $(0.9)$, negative, and significant $(\mathrm{p}<0.05)$ for each agroindustrial compound. That is, the higher the $\mathrm{BCW}$ dose added to the organic compound, the lower the substrates' EC. Increased EC due to higher amounts of organic compost in substrates has also been reported in other studies (Bustamante et al., 2008; Gavilanes-Terán et al., 2017). Despite a decrease in soluble salt concentration caused by the addition of $\mathrm{BCW}$, all 25 prepared substrates presented $\mathrm{EC}$ and $\mathrm{pH}$ above the range considered ideal by Abad et al. (2001) (Table 3).

The addition of $\mathrm{BCW}$ doses to agro-industrial compost increased $(p<0.05)$ substrate alkalinity. For all types of compost (A, P, S, B and N), it was found that the highest $\mathrm{pH}$ values were obtained in the substrates with the highest percentages of added BCW (Table 3). Since BCW has a $\mathrm{pH}$ of 10.3 (Table 2), it contributed to substrate alkalinity. Research in which biochar, a component with characteristics similar to $\mathrm{BCW}$, was added to growth media, also found a rise in substrate $\mathrm{pH}$ Steiner \& Harttung, 2014; Kaudal et al.,2016).

The increasing addition of $\mathrm{BCW}$ to agro-industrial compost decreased the HLIF aromaticity index in all substrates (Table 3). This index reflects the degree of 
humification of substrate organic matter, being able to identify fluorescent groups, such as aromatic rings and quinones (Milori et al., 2006). Higher HLIF index values indicate a higher concentration of fluorescent groups compared to total organic carbon in the substrate, that is, a higher degree of humification. When embedded into substrates, BCW's low aromaticity (HLIF index) (Table 2) generated a dilution effect on the concentration of aromatic compounds present in the agro-industrial compost, decreasing the degree of substrate humification with the addition of increasing doses of $\mathrm{BCW}$.
BCW's low bulk density (BD) (Table 2) caused a significant decrease in $\mathrm{BD}$ in all substrates as $\mathrm{BCW}$ doses increased (15, 30, 45 and 60\%) (Table 4). Research has found that higher proportions of agro-industrial compost added to substrates lead to increased BD (Bustamante et al., 2008; Gavilanes-Terán et al.,2017). Substrates A0, P0 and $\mathrm{B} 0$, prepared without the addition of $\mathrm{BCW}$ (100\% agroindustrial compost), presented above-optimal BD values $\left(\leq 0.4 \mathrm{~g} . \mathrm{cm}^{-3}\right)$ (Abad et al., 2001). The addition of $15 \%$ $\mathrm{BCW}$ or more to these substrates allowed them to reach optimal BD values (Table 4).

TABLE 4. Bulk density (BD), Total porosity (TP), Aeration Porosity (AP), water-holding porosity (WHP) and total waterholding capacity (TWHC), of 25 substrates and commercial substrate (CS).

\begin{tabular}{|c|c|c|c|c|c|c|}
\hline Substrates & $\begin{array}{c}\text { BCW } \\
\%\end{array}$ & $\begin{array}{c}\mathrm{BD} \\
\left(\mathrm{g} \cdot \mathrm{cm}^{-3}\right)\end{array}$ & $\begin{array}{l}\mathrm{TP} \\
\%\end{array}$ & $\begin{array}{l}\text { AP } \\
\%\end{array}$ & $\begin{array}{c}\text { WHP } \\
\%\end{array}$ & $\begin{array}{l}\text { TWHC } \\
\left(\mathrm{mL} \cdot \mathrm{L}^{-1}\right)\end{array}$ \\
\hline IS $^{\mathrm{g}}$ & & $\leq 0,40$ & $>85$ & $20-30$ & & $600-1000$ \\
\hline A0 & 0 & $0.43 \mathrm{a}$ & $71 \mathrm{~b}$ & $2.5 \mathrm{~b}$ & $68 \mathrm{a}$ & $684 \mathrm{~b}$ \\
\hline A15 & 15 & $0.36 \mathrm{~b}$ & $78 \mathrm{a}$ & $4.5 \mathrm{a}$ & $74 \mathrm{a}$ & $737 \mathrm{a}$ \\
\hline A 30 & 30 & $0.33 \mathrm{~b}$ & $77 \mathrm{a}$ & $3.2 \mathrm{ab}$ & $74 \mathrm{a}$ & $741 \mathrm{a}$ \\
\hline A45 & 45 & $0.29 \mathrm{c}$ & $77 \mathrm{a}$ & $4.1 \mathrm{ab}$ & $73 \mathrm{a}$ & $733 a b$ \\
\hline A60 & 60 & $0.23 \mathrm{c}$ & $75 \mathrm{ab}$ & $4.1 \mathrm{ab}$ & $71 \mathrm{a}$ & $711 \mathrm{~b}$ \\
\hline $\mathrm{P} 0$ & 0 & $0.41 \mathrm{a}$ & $62 \mathrm{c}$ & $7.6 \mathrm{a}$ & $55 \mathrm{c}$ & $547 \mathrm{c}$ \\
\hline P15 & 15 & $0.33 \mathrm{~b}$ & $78 \mathrm{a}$ & $4.7 \mathrm{~b}$ & $73 \mathrm{a}$ & $731 \mathrm{a}$ \\
\hline P30 & 30 & $0.30 \mathrm{c}$ & $79 a$ & $4.6 \mathrm{~b}$ & $75 \mathrm{a}$ & $747 \mathrm{a}$ \\
\hline P45 & 45 & $0.26 \mathrm{~d}$ & $76 \mathrm{a}$ & $3.4 \mathrm{~b}$ & $73 \mathrm{a}$ & $727 \mathrm{a}$ \\
\hline P60 & 60 & $0.25 \mathrm{~d}$ & $71 \mathrm{~b}$ & $3.8 \mathrm{~b}$ & $67 \mathrm{~b}$ & $674 b$ \\
\hline S0 & 0 & $0.42 \mathrm{a}$ & $79 \mathrm{ab}$ & $1.5 \mathrm{~b}$ & $78 \mathrm{a}$ & $778 \mathrm{a}$ \\
\hline S15 & 15 & $0.33 \mathrm{~b}$ & $77 \mathrm{~b}$ & $1.8 \mathrm{~b}$ & $75 \mathrm{ab}$ & $752 \mathrm{ab}$ \\
\hline $\mathrm{S} 30$ & 30 & $0.29 \mathrm{c}$ & $81 \mathrm{a}$ & $2.8 \mathrm{a}$ & $79 \mathrm{a}$ & $786 \mathrm{a}$ \\
\hline $\mathrm{S} 45$ & 45 & $0.25 \mathrm{~d}$ & $75 \mathrm{bc}$ & $3.2 \mathrm{a}$ & $72 \mathrm{bc}$ & 720 bc \\
\hline S60 & 60 & $0.26 \mathrm{~d}$ & $71 \mathrm{c}$ & $3.3 \mathrm{a}$ & $68 \mathrm{c}$ & $680 \mathrm{c}$ \\
\hline B0 & 0 & $0.31 \mathrm{a}$ & $68 c$ & $7.2 \mathrm{a}$ & $61 \mathrm{c}$ & $607 c$ \\
\hline B15 & 15 & $0.28 \mathrm{~b}$ & $71 \mathrm{bc}$ & $6.0 \mathrm{ab}$ & $65 \mathrm{~b}$ & $653 \mathrm{~b}$ \\
\hline B30 & 30 & $0.26 \mathrm{c}$ & $75 \mathrm{a}$ & $3.3 \mathrm{c}$ & $72 \mathrm{a}$ & $717 \mathrm{a}$ \\
\hline B45 & 45 & $0.24 \mathrm{~d}$ & $75 \mathrm{ab}$ & $3.9 \mathrm{bc}$ & $71 \mathrm{a}$ & $707 \mathrm{a}$ \\
\hline B60 & 60 & $0.23 \mathrm{~d}$ & $74 \mathrm{~b}$ & $3.5 \mathrm{c}$ & $71 \mathrm{a}$ & $705 \mathrm{ab}$ \\
\hline N0 & 0 & $0.33 \mathrm{a}$ & $82 \mathrm{ab}$ & $7.3 \mathrm{a}$ & $75 \mathrm{a}$ & $746 \mathrm{ab}$ \\
\hline N15 & 15 & $0.31 \mathrm{~b}$ & $84 \mathrm{a}$ & $6.3 \mathrm{a}$ & $77 \mathrm{a}$ & $772 \mathrm{a}$ \\
\hline N30 & 30 & $0.28 \mathrm{c}$ & $84 \mathrm{a}$ & $6.6 \mathrm{a}$ & $78 \mathrm{a}$ & $777 \mathrm{a}$ \\
\hline N45 & 45 & $0.24 \mathrm{~d}$ & $79 b$ & $4.4 \mathrm{~b}$ & $75 \mathrm{a}$ & $748 \mathrm{ab}$ \\
\hline N60 & 60 & $0.22 \mathrm{e}$ & $74 \mathrm{c}$ & $4.4 \mathrm{~b}$ & $70 \mathrm{a}$ & $700 \mathrm{~b}$ \\
\hline $\mathrm{CS}$ & 0 & 0.38 & 72 & 6.5 & 66 & 659 \\
\hline
\end{tabular}

BCW: boiler remnant charcoal waste; ${ }^{g}$ Optimum or acceptable values for an ideal substrate according to Abad et al. (2004); Equal lowercase letters show no significant minimum difference (LSD) by the F test ( $\alpha$ : 5\%) among the BCW doses added in each agro-industrial compost.

Overall, the relationship between $\mathrm{TP}$ and the increment of $\mathrm{BCW}$ in substrates did not have a linear behavior. That is, the addition of BCW to the compost did not lead to higher TP (Table 4). The highest TPs were found in substrates with doses between 15 and $45 \%$ BCW. However, none of the 26 substrates $(25$ prepared + CS $)$ reached $\mathrm{TP}>85 \%$, considered optimal (Abad et al., 2001). The addition of BCW favored an increase in AP, especially in substrates with fine grain size (cotton and wood sawdust). The larger volume of particles size $>1 \mathrm{~mm}$ favored clod formation by root folding (Bustamante et al., 2008). Regarding WHP, treatments in which cotton and Napier 
grass were used as the main carbon sources during composting were not significantly affected by the addition of BCW. Among the other treatments, the most pronounced effects occurred when tree pruning and sugarcane bagasse were used in the process. The grain size of these materials, when used as BAs, allowed $\mathrm{BCW}$ addition to improve substrate texture for water holding, as shown in TWHC (Table 4), which did not occur for other BAs (A, S and N).

\section{Effect of substrates on lettuce seedling development and quality}

The diluent effect of the increasing addition of $\mathrm{BCW}$ $(15,30,45$ and $60 \%)$ on the EC of the agro-industrial compost increased the percentage of $\mathrm{E}$ and ESI. As a result, the number of days required for seeds to emerge (MET) decreased $(p<0.05)$. That is, the higher the BCW dose in the preparation of the 25 substrates, the lower the MET and the higher the E and ESI of lettuce seedlings (Table 5). In this sense, the decrease in EC caused both by the addition of BCW (Table 3) and salt leaching during the experiment (Menezes Júnior et al., 2000) favors the results of E, ESI and MET.

However, this effect of higher BCW percentages leading to better development of seedlings did not occur for seedling quality (SQI) after 30 days of cultivation. That is, SQI showed that seedlings do not present higher quality due only to a greater reduction of substrate EC. With the exception of substrates prepared with $\mathrm{A}$ and $\mathrm{N}$ which had the highest EC values (Table 3$)$, the highest $(\mathrm{p}<0.05) \mathrm{SQI}$ values were found in substrates prepared with 15 to $45 \%$ BCW (Table 5), which did not have the lowest EC values (Table 3).

TABLE 5. Emergence, development and quality of lettuce seedlings and clod properties after 30-days culture of tray.

\begin{tabular}{|c|c|c|c|c|c|c|c|c|}
\hline Substrates & $\begin{array}{c}\text { BCW } \\
(\%) \\
\end{array}$ & $\begin{array}{c}\mathrm{E} \\
(\%) \\
\end{array}$ & ESI & $\begin{array}{l}\text { MET } \\
\text { (days) }\end{array}$ & SQI & TChl & ERT & $\mathrm{CSt}$ \\
\hline $\mathrm{A} 0$ & 0 & $10 \mathrm{~d}$ & $0.5 \mathrm{~d}$ & $7.1 \mathrm{a}$ & $0.0001 \mathrm{c}^{\mathrm{M}}$ & ND & ND & ND \\
\hline A 15 & 15 & $28 \mathrm{c}$ & $1.3 \mathrm{~d}$ & $7.5 \mathrm{a}$ & $0.0027 \mathrm{~b}^{\mathrm{L}}$ & $0.42^{\mathrm{ns}}$ & $6.0 \mathrm{c}$ & $7.1 \mathrm{a}$ \\
\hline $\mathrm{A} 30$ & 30 & $58 \mathrm{~b}$ & $2.8 \mathrm{c}$ & $7.0 \mathrm{a}$ & $0.0031 b^{L}$ & $0.41^{\mathrm{ns}}$ & $8.0 \mathrm{a}$ & $7.1 \mathrm{a}$ \\
\hline A45 & 45 & $69 b$ & $4.2 \mathrm{~b}$ & $5.2 \mathrm{~b}$ & $0.0080 \mathrm{a}^{\mathrm{J}}$ & $0.39^{\mathrm{ns}}$ & $6.8 \mathrm{~b}$ & $6.4 \mathrm{ab}$ \\
\hline A60 & 60 & $87 \mathrm{a}$ & $5.9 \mathrm{a}$ & $4.6 \mathrm{~b}$ & $0.0089 \mathrm{a}^{\mathrm{IJ}}$ & $0.40^{\mathrm{ns}}$ & $5.1 \mathrm{~d}$ & $4.8 \mathrm{~b}$ \\
\hline $\mathrm{P} 0$ & 0 & $77 \mathrm{~b}$ & $4.1 \mathrm{c}$ & $6.1 \mathrm{a}$ & $0.0122 b^{\mathrm{FG}}$ & $0.19 \mathrm{~b}$ & $7.1 \mathrm{~b}$ & $5.9 \mathrm{ab}$ \\
\hline $\mathrm{P} 15$ & 15 & $77 \mathrm{~b}$ & $4.1 \mathrm{c}$ & $6.1 \mathrm{a}$ & $0.0148 \mathrm{a}^{\mathrm{AB}}$ & $0.31 \mathrm{a}$ & $7.8 \mathrm{a}$ & $6.5 \mathrm{a}$ \\
\hline P30 & 30 & $84 \mathrm{ab}$ & $5.6 \mathrm{~b}$ & $4.8 \mathrm{~b}$ & $0.0153 \mathrm{a}^{\mathrm{A}}$ & $0.25 \mathrm{ab}$ & $7.9 \mathrm{a}$ & $6.3 \mathrm{ab}$ \\
\hline $\mathrm{P} 45$ & 45 & $97 \mathrm{a}$ & $7.1 \mathrm{a}$ & $4.3 \mathrm{~b}$ & $0.0139 a b^{B C D}$ & $0.29 \mathrm{a}$ & $7.1 \mathrm{~b}$ & $5.5 \mathrm{bc}$ \\
\hline $\mathrm{P} 60$ & 60 & $94 \mathrm{a}$ & $6.8 \mathrm{ab}$ & $4.3 \mathrm{~b}$ & $0.0127 b^{\mathrm{EF}}$ & $0.26 \mathrm{ab}$ & $5.4 \mathrm{c}$ & $4.9 \mathrm{c}$ \\
\hline S0 & 0 & $70 \mathrm{c}$ & $3.8 \mathrm{c}$ & $5.7 \mathrm{a}$ & $0.0124 \mathrm{~b}^{\mathrm{FG}}$ & $0.27^{\mathrm{ns}}$ & $4.6 \mathrm{~d}$ & $5.0 \mathrm{~d}$ \\
\hline $\mathrm{S} 15$ & 15 & $84 b$ & $5.6 \mathrm{~b}$ & $4.7 \mathrm{~b}$ & $0.0133 a b^{C D E F}$ & $0.36^{\mathrm{ns}}$ & $8.0 \mathrm{ab}$ & $7.0 \mathrm{~b}$ \\
\hline $\mathrm{S} 30$ & 30 & $97 \mathrm{a}$ & $7.1 \mathrm{a}$ & $4.2 \mathrm{c}$ & $0.0138 \mathrm{a}^{\mathrm{BCD}}$ & $0.32^{\mathrm{ns}}$ & $8.6 \mathrm{a}$ & $7.4 \mathrm{ab}$ \\
\hline $\mathrm{S} 45$ & 45 & $98 \mathrm{a}$ & $7.5 \mathrm{a}$ & $4.1 \mathrm{c}$ & $0.0114 \mathrm{c}^{\mathrm{G}}$ & $0.35^{\mathrm{ns}}$ & $7.4 \mathrm{bc}$ & $8.0 \mathrm{a}$ \\
\hline $\mathrm{S} 60$ & 60 & $93 \mathrm{a}$ & $7.4 \mathrm{a}$ & $4.0 \mathrm{c}$ & $0.0101 \mathrm{~d}^{\mathrm{H}}$ & $0.33^{\mathrm{ns}}$ & $6.8 \mathrm{c}$ & $6.1 \mathrm{c}$ \\
\hline B0 & 0 & $82 \mathrm{c}$ & $4.3 \mathrm{c}$ & $6.0 \mathrm{a}$ & $0.0082 \mathrm{~d}^{\mathrm{J}}$ & $0.28^{\mathrm{ns}}$ & $7.1 \mathrm{ab}$ & $7.6 \mathrm{ab}$ \\
\hline B15 & 15 & $86 \mathrm{bc}$ & $4.8 \mathrm{bc}$ & $5.8 \mathrm{a}$ & $0.0129 \mathrm{c}^{\mathrm{DEF}}$ & $0.33^{\text {ns }}$ & $8.0 \mathrm{a}$ & $8.0 \mathrm{a}$ \\
\hline $\mathrm{B} 30$ & 30 & $91 \mathrm{ab}$ & $6.0 \mathrm{ab}$ & $4.8 \mathrm{~b}$ & $0.0144 \mathrm{a}^{\mathrm{ABC}}$ & $0.31^{\mathrm{ns}}$ & $8.5 \mathrm{a}$ & $8.6 \mathrm{a}$ \\
\hline B45 & 45 & $96 \mathrm{a}$ & $6.9 \mathrm{a}$ & $4.4 \mathrm{bc}$ & $0.0138 a b^{B C D E}$ & $0.33^{\mathrm{ns}}$ & $7.9 \mathrm{a}$ & $8.1 \mathrm{a}$ \\
\hline $\mathrm{B} 60$ & 60 & $98 \mathrm{a}$ & $7.5 \mathrm{a}$ & $4.0 \mathrm{c}$ & $0.0132 \mathrm{bc}^{\mathrm{DEF}}$ & $0.36^{\mathrm{ns}}$ & $6.4 \mathrm{~b}$ & $6.6 \mathrm{~b}$ \\
\hline N0 & 0 & $3.3 \mathrm{c}$ & $0.1 \mathrm{c}$ & $10.3 \mathrm{ab}$ & $0.0000 \mathrm{~d}^{\mathrm{M}}$ & ND & ND & ND \\
\hline N15 & 15 & $3.3 \mathrm{c}$ & $0.1 \mathrm{c}$ & $11.1 \mathrm{a}$ & $0.0009 \mathrm{~cd}^{\mathrm{M}}$ & $0.30^{\mathrm{ns}}$ & $5.5 \mathrm{~b}$ & $6.0^{\mathrm{ns}}$ \\
\hline N30 & 30 & $9.2 \mathrm{c}$ & $0.4 \mathrm{c}$ & $8.3 \mathrm{~b}$ & $0.0024 \mathrm{c}^{\mathrm{L}}$ & $0.29^{\mathrm{ns}}$ & $7.5 \mathrm{a}$ & $6.4^{\mathrm{ns}}$ \\
\hline N45 & 45 & $29 \mathrm{~b}$ & $1.7 \mathrm{~b}$ & $5.8 \mathrm{c}$ & $0.0046 b^{\mathrm{K}}$ & $0.26^{\mathrm{ns}}$ & $7.0 \mathrm{a}$ & $6.1^{\mathrm{ns}}$ \\
\hline N60 & 60 & $48 \mathrm{a}$ & $3.3 \mathrm{a}$ & $4.6 \mathrm{c}$ & $0.0096 \mathrm{a}^{\mathrm{HI}}$ & $0.27^{\mathrm{ns}}$ & $6.3 \mathrm{~b}$ & $6.0^{\mathrm{ns}}$ \\
\hline $\mathrm{CS}$ & 0 & 96 & 7.7 & 3.9 & $0.0085^{\mathrm{IJ}}$ & 0.21 & 7.6 & 6.6 \\
\hline
\end{tabular}

CS: commercial substrate; E: Emergence percentage; ESI: emergence speed index; MET: mean emergence time; SQI: seedling quality index; TChl: Total chlorophyll; ERT: easiness of removal of clod from tray; CSt: clod stability; ND: Not determined; ns: no significance. Equal lowercase letters do not show a significant minimum difference (LSD) by the F test ( $\alpha$ : $5 \%)$ among the BCW doses added in each agroindustrial compost, and the equal uppercase superscript letters do not differ compared to all substrates. 
Percentages lower than $60 \% \mathrm{BCW}$ in compost types $\mathrm{A}$ and $\mathrm{N}$ generated seedlings with lower SQI values $(p<0.05)$ compared to the CS. Only A60, N60 and B0 produced seedlings equivalent $(\mathrm{p}<0.05)$ to the $\mathrm{CS}$, while all the other 22 prepared substrates produced seedlings with higher SQIs $(\mathrm{p}>0.05)$, although none of the prepared substrates presented EC values within the optimal range for the production of vegetable seedlings $\left(0.75-2.0^{\mathrm{dS} . \mathrm{m}-1}\right)$ (Table 3).

There was practically no significant difference in total chlorophyll (TChl) among lettuce seedlings (Table 5). Therefore, BCW added to agro-industrial compost has no effect on the chlorophyll concentration of seedlings.
However, BCW percentages significantly changed clod properties (ERT and CE) after cultivation (Table 5). In general, the BCW doses that facilitated clod removal from tray the most (highest ERT), were the ones between 15 and $45 \%$. Doses above or below this interval presented lower $\mathrm{CE}$ and greater removal difficulty (clod stuck to tray or broken when removed).

In short, the interpretation of seedling quality and development and clod stability properties (Table 5) can be summarized by PCA, expressed in two main components (CP1 and $\mathrm{CP} 2)$. Together, these components explained $87.6 \%$ of the total variance of substrate data. The biplots (A and $\mathrm{B})$ generated with $\mathrm{CP} 1$ and $\mathrm{CP} 2$ are shown in Figure 1.
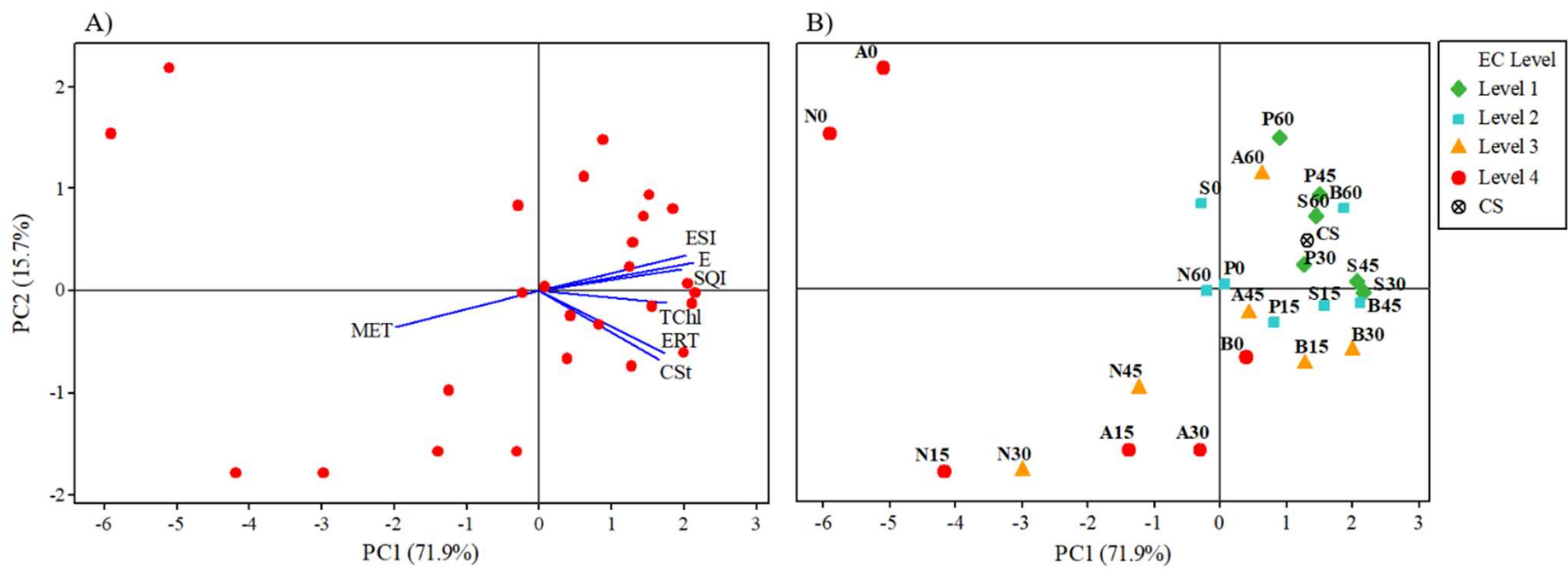

FIGURE 1. Biplot graphics generated from the PCA with the two main components (PC1 and PC2). A) Loadings Plot of the seven variables used. B) Score Plot of the 26 substrates (25 elaborated + CS), categorized according to the level of electrical conductivity (EC).

CP1, with $71.9 \%$ of accumulated explanation percentage, was positively correlated with all variables except MET, with which it correlated negatively (Figure 1A). Thus, substrate positions further to the left along the CP1 axis indicate slower emergence (higher MET), with poor development (lower E and ESI) and lower quality (low SQI).

The Score Plot in Figure 1B shows the position of the 26 substrates and their categorization into four EC levels. These levels were divided into Level $1\left(2>5 \mathrm{dS} . \mathrm{m}^{-}\right.$ $\left.{ }^{1}\right)$, level $2\left(5 \geq 6.5 \mathrm{dS} \cdot \mathrm{m}^{-1}\right)$, level $3\left(6.5>9 \mathrm{dS} . \mathrm{m}^{-1}\right)$ and level $4\left(9 \geq 18 \mathrm{dS} \cdot \mathrm{m}^{-1}\right)$. In this case, substrates N0, N15, N30, $\mathrm{N} 45, \mathrm{~A} 0, \mathrm{~A} 15$ and A30 (located in the left area of the CP1 axis) provided the lowest E, ESI and SQI values, as well as the highest MET. All these substrates are classified as level 3 or 4 , the highest salinity levels $\left(6.5 \geq 18 \mathrm{mS}^{-1} \mathrm{~m}^{-1}\right.$. According to Gavilanes-Terán et al. (2017) when substrates present high initial EC, phytotoxic components inhibit seed emergence. In this sense, agro-industrial compost in which Napier grass $(\mathrm{N})$ and cotton $(\mathrm{C})$ were used as structuring agents proved to be not viable for Lucy Brown lettuce production, presenting poor development (E and ESI) and low seedling quality (SQI) (Table 5). The excess of nutrients contained in these types of compost caused a phytotoxic effect on lettuce seedlings (Santos et al., 2015).

The variables ERT and CE are explained partly by CP1 and partly by CP2 (15.7\%). The substrates that presented the highest values for these variables were those prepared with the compost in which tree pruning $(\mathrm{P})$, wood sawdust (S) and sugarcane bagasse (B) were used as structuring agents in the composting process. The lowest ERT and CE values were found in the treatments in which Napier grass (N) and cotton (C) were used, disqualifying them as satisfactory substrates for seedling production. ERT and $\mathrm{CE}$ are important variables for the assessment of seedling production, since they both influence postcultivation stages such as transport, transplanting and permanent planting (Kratz et al., 2015).

\section{Relevance of substrate characteristics to seedling quality}

Among the 13 chemical, physical and physicochemical variables analyzed in the substrates, the three most relevant $(\mathrm{N}, \mathrm{EC}$ and $\mathrm{pH})$ can significantly explain $81 \%$ of the quality of lettuce seedlings (SQI). This proportion of mean SQI explanation is given by the estimated model of multiple linear regression (MLR) (Equation 1). With this model, and based on the data of $\mathrm{N}$, $\mathrm{EC}$ and $\mathrm{pH}$ of substrates prepared with BPC agro-industrial compost and $\mathrm{BCW}$ doses, it is possible to predict seedling quality (SQI) after 30 days of cultivation even before sowing.

The MLR model was estimated with 48 observations and is significant at $1 \%(\mathrm{p}<0.01)$ of probability and $\mathrm{F}$ value of 64.4 , according to the analysis of variance. Its coefficient of determination $\mathrm{R}^{2}$ was $81.4 \%$ and the adjusted $\mathrm{R}^{2}$ was $80.9 \%$. This MLR model (Eq. 1) revealed that for each $1 \%$ increase in the nitrogen $(\mathrm{N})$ content of substrates, SQI increases by 0.00233 when other variables remain constant. Therefore, there will also be an equivalent decrease in SQI for each 1\% decrease in the concentration of $\mathrm{N}$ in the substrates. 
The EC coefficient of the estimated model (Equation 1) had a negative sign, that is, an increase in EC leads to a decrease in seedling quality. It can be inferred that for each reduction of $1 \mathrm{dS} . \mathrm{m}^{-1}$ in substrate $\mathrm{EC}$, there is an increase in SQI of 0.00153 . In this case, the model confirms the detrimental effects of high salinity on seedling development (Spiassi et al., 2015; Gavilanes-Terán et al., 2017). Regarding the $\mathrm{pH}$, the model demonstrated that for each unit of $\mathrm{pH}$ reduced, seedling quality (SQI) increases by 0.00335 . Due to the $\mathrm{pH}$ range (6.9 to 8.9) of the prepared substrates (Table 3), the $\mathrm{pH}$ coefficient was negative, demonstrating that in order to increase SQI, substrate $\mathrm{pH}$ must decrease, approaching the optimal range (5.3 to 6.5). Alkaline $\mathrm{pH}$ impairs substrates' cation exchange capacity, decreasing nutrient absorption (Abad et al., 2001) and consequently gaining less mass, which can be verified by lower SQIs (Table 5). Increased SQIs correspond to the ability of substrates to generate plants with better mass distributions (Meng et al., 2018).

\section{Substrate preparation for maximum quality and easier removal from tray}

The ideal BCW dose required for seedlings to reach maximum quality $\left(\mathrm{SQI}_{\max }\right)$ and maximum easiness of removal from tray $\left(\mathrm{ERT}_{\max }\right)$ for each agro-industrial compound studied (A, P, S, B and N), was determined by extracting the maximum point of the quadratic functions of the estimated models. Optimal $\mathrm{BCW}$ doses to achieve theoretical SQI $\mathrm{max}_{\max }$ are presented in Table 6.

TABLE 6. Ideal dose of boiler remnant charcoal waste (BCW) percentage to be added in each agro-industrial compost to reach the maximum theoretical SQI.

\begin{tabular}{cccccc}
\hline Substrate & Ideal BCW (\%) & SQI máx & Quadratic model & p-value & $\begin{array}{c}\mathbf{R}^{\mathbf{2}} \\
\text { adjust. }\end{array}$ \\
\hline $\mathbf{A}$ & $\geq 60$ & 0.0091 & SQI A $=0.00013+0.000131(\mathrm{BCW})+0.000000(\mathrm{BCW})^{2}$ & 0.707 & $\mathrm{~ns}$ \\
$\mathbf{P}$ & 33.0 & 0.0152 & $\mathrm{SQI} \mathrm{P}=0.01239+0.000183(\mathrm{BCW})-0.000003(\mathrm{BCW})^{2}$ & 0.002 & $70 \%$ \\
$\mathbf{S}$ & 24.0 & 0.0136 & $\mathrm{SQI} \mathrm{S}=0.01247+0.000096(\mathrm{BCW})-0.000002(\mathrm{BCW})^{2}$ & 0.003 & $82 \%$ \\
$\mathbf{B}$ & 39.6 & 0.0147 & $\mathrm{SQI} \mathrm{B}=0.00846+0.000317(\mathrm{BCW})-0.000004(\mathrm{BCW})^{2}$ & 0.000 & $93 \%$ \\
$\mathbf{N}$ & $\geq 60$ & 0.0081 & $\mathrm{SQI} \mathrm{N}=0.00020-0.000017(\mathrm{BCW})+0.000003(\mathrm{BCW})^{2}$ & 0.305 & $\mathrm{~ns}$ \\
\hline
\end{tabular}

The quadratic model was not significant only for mixtures derived from organic compost using waste from cotton $(\mathrm{C})$ and Napier grass $(\mathrm{N})$ shredding as carbon sources in the composting process. This was due to the chemical characteristics of these two organic compounds, especially the high salinity (Table 3$)$, level 3 and $4\left(6.5 \geq 18 \mathrm{mS} . \mathrm{m}^{-1}\right)$ (Figure 1B). Although the addition of $\mathrm{BCW}$ causes a decrease in EC values, optimal conditions for seedling development were not reached, even with the addition of $60 \% \mathrm{BCW}$ to substrate composition, which disqualifies both for use as substrate. For these two sources, the more BCW was added, the higher the SQI, demonstrating a linear behavior, not a quadratic function (not significant) (Table 6). Thus, it can be said that reaching the theoretical SQI $\mathrm{Imax}_{\text {for }}$
$\mathrm{A}$ and $\mathrm{N}$ would require $\mathrm{BCW}$ doses greater than or equal to $60 \%(\geq 60 \%)$.

Regarding the other three substrates, prepared with organic compost in which tree pruning $(\mathrm{P})$, wood sawdust (S) and sugarcane bagasse (B) were used, regression models showed that for lettuce seedlings to reach $\mathrm{SQI}_{\max }$, the $\mathrm{BCW}$ doses that need to be added are 33, 24 and $39.6 \%$, respectively. Azevedo et al. (2010) affirm that SQI is a good indicator of seedling quality, because it takes into account the robustness and balance of the biomass distribution within the seedling for its calculation.

For maximum easiness of clod removal from tray $\left(\mathrm{ERT}_{\max }\right)$ optimal BCW doses were found for each compound $(\mathrm{A}, \mathrm{P}, \mathrm{S}, \mathrm{B}$ and $\mathrm{N})$ and are summarized in Table 7.

TABLE 7. Ideal dose of boiler remnant charcoal waste (BCW) percentage to be added in each agro-industrial compost to reach the maximum theoretical ERT.

\begin{tabular}{cccccc}
\hline Substrate & $\begin{array}{c}\text { Ideal BCW } \\
\text { (\%) }\end{array}$ & ERT $_{\text {max }}$ & \multicolumn{1}{c}{ Quadratic model } & p-value & $\mathbf{R}^{2}$ adjust. \\
\hline A & 34.5 & 7.7 & ERT A $=2.906+0.276(\mathrm{BCW})-0.00403(\mathrm{BCW})^{2}$ & 0.002 & $85 \%$ \\
P & 23.0 & 8.0 & ERT P $=7.016+0.083(\mathrm{BCW})-0.00182(\mathrm{BCW})^{2}$ & 0.000 & $98 \%$ \\
S & 34.2 & 8.6 & ERT S $=4.939+0.212(\mathrm{BCW})-0.00313(\mathrm{BCW})^{2}$ & 0.001 & $81 \%$ \\
B & 26.6 & 8.4 & ERT B $=7.061+0.101(\mathrm{BCW})-0.00186(\mathrm{BCW})^{2}$ & 0.002 & $72 \%$ \\
N & 38.8 & 7.4 & ERT N $=2.688+0.241(\mathrm{BCW})-0.00306(\mathrm{BCW})^{2}$ & 0.002 & $85 \%$ \\
\hline
\end{tabular}

ERT is an important parameter, as clod aggregation will give the seedling better survival conditions in the field after transplanting. Boene et al. (2013) assessed the easiness of removal of seedlings from tubes and root adherence to substrates. The authors found that substrate components such as carbonized rice husks and coconut fibers were very loose materials, making it difficult for roots to adhere to clods and, consequently, remove tubes without damaging seedlings.

In this study, it was found that the substrates that received the highest scores in the ERT assessment $(>8.0)$ were the ones that used tree pruning $(\mathrm{P})$, wood sawdust $(\mathrm{S})$ 
and sugarcane bagasse (B) as structuring agents in the composting process. Thus, it can be inferred that seedlings originating from these substrates will have a better development and greater survival capacity in the field (Kratz et al., 2015). The BCW doses, in dry mass, required for substrates prepared with $\mathrm{P}, \mathrm{S}$ and $\mathrm{B}$ to reach the theoretical $\mathrm{ERT}_{\max }$ are 23, 34.2 and $26.6 \%$, respectively. The averages of the optimal BCW doses for SQI $\mathrm{I}_{\max }$ and $\mathrm{ERT}_{\text {max }}$ of these substrates are 28, 29 and 33\%, respectively. Therefore, for the preparation of substrates originating from $\mathrm{BPC}$ agro-industrial compost and $\mathrm{BCW}$ with maximum quality and easiest removal from tray, the recommended $\mathrm{BCW}$ percentage is approximately $30 \%$ in dry mass.

\section{CONCLUSIONS}

The addition of boiler remnant charcoal waste $(\mathrm{BCW})$ to organic compost reduces the electrical conductivity of the mixture (substrates). Among the chemical, physical and physicochemical variables of the substrates, total nitrogen content, electrical conductivity and $\mathrm{pH}$ are the most important variables to explain seedling quality index (SQI). The percentage of BCW added to substrates directly influences the easiness of removal of clod from tray.

Cotton and Napier grass shredding waste, when used as a structuring agent and carbon source for the BPC waste composting process, generates an organic compost with high EC, which is not suitable for the preparation of horticultural substrates.

The use of more sturdy carbon sources in the BPC waste composting process, such as urban tree pruning, wood sawdust or crushed sugarcane bagasse, generates compost that is more suitable for the purpose of producing vegetable substrates. The addition of $30 \%$ in dry matter of boiler remnant charcoal to this compost is recommended to obtain maximum quality seedlings, which are superior to commercial substrate and easy to remove from tray.

\section{ACKNOWLEDGEMENTS}

We thank the Western Parana State University and the support of the Higher Education Personnel Improvement Coordination - Brazil (CAPES) - Financing Code 001 .

\section{REFERENCES}

Abad M, Noguera P, Burés S (2001) National inventory of organic wastes for use as growing media for ornamental potted plant production: Case study in Spain. Bioresource Technology 77(2):197-200. DOI:

https://doi.org/10.1016/S0960-8524(00)00152-8

Abad M (2004) Los sustratos en los cultivos sin suelo. In: Abad M, Noguera P, Carrión CB. Tratado de cultivo sin suelo. Madrid, Mundi-Prensa, p113-158.

Arnon DI (1949) Copper enzymes in isolated chloroplasts. Polyphenoloxidase in Beta vulgaris. Plant Physiology 24(1):1-15. DOI: https://dx.doi.org/10.1104/pp.24.1.1

Azevedo IMG, Alencar RM, Barbosa AP, Almeida NO (2010) Estudo do crescimento e qualidade de mudas de marupá (Simarouba amara Aubl.) em viveiro. Acta Amazonica 40(1):157-164. DOI: https://dx.doi.org/10.1590/S0044-59672010000100020
Bernardi FH, Costa MSSM, Costa LAM, Damaceno FM, Chiarelotto M (2018) Microbiological activity during the composting of wastes from broiler productive chain. Engenharia Agrícola 38(5):741-750. DOI: https://dx.doi.org/10.1590/1809-4430-eng.agric.v38n5p741$750 / 2018$

Bilderback TE, Warren SL, Owem JR, Albano JP (2005) Healthy substrates need physicals too! HortTechnology 15(4):747-751.

Boene HCAM, Nogueira AC, Sousa NJ, Kratz D, Souza PVD (2013) Efeitos de diferentes substratos na produção de mudas de Sebastiania commersoniana. Floresta 43(3):407-420. DOI: http://dx.doi.org/10.5380/rf.v43i3.25789

Bustamante MA, Paredes C, Moral R, Agulló E, PérezMurcia MD, Abad M (2008) Composts from distillery wastes as peat substitutes for transplant production. Resources, Conservation and Recycling 52(5):792-799. DOI: https://dx.doi.org/10.1016/j.resconrec.2007.11.005

Carmo DL, Silva CA (2012) Métodos de quantificação de carbono e matéria orgânica em resíduos orgânicos. Revista Brasileira de Ciência do Solo 36(4):1211-1220. DOI: http://dx.doi.org/10.1590/S0100-06832012000400015

Costa MSSM, Bernardi FH, Costa LAM, Pereira DC, Lorin HEF, Rozatti MAT, Carneiro LJ (2017) Composting as a cleaner strategy to broiler agro-industrial wastes: Selecting carbon source to optimize the process and improve the quality of the final compost. Journal of Cleaner Production 142:2084-2092. DOI: https://dx.doi.org/10.1016/j.jclepro.2016.11.075

Costa MSSM, Lorin HEF, Costa LAM, Cestonaro T, Pereira DC, Bernardi FH (2016) Performance of four stabilization bioprocesses of beef cattle feedlot manure. Journal of Environmental Management 181:443-448. DOI: https://doi.org/10.1016/j.jenvman.2016.07.003

Dickson A, Leaf AL, Hosner JF (1960) Quality appraisal of white spruce and white pine seedling stock in nurseries. The Forestry Chronicle 36(1):10-13. DOI: https://dx.doi.org/10.5558/tfc36010-1

Embrapa - Empresa Brasileira de Pesquisa Agropecuária (2009) Manual de análises químicas do solo, plantas e fertilizantes. Brasília, Embrapa informação tecnológica, 2 ed. $627 \mathrm{p}$.

Gavilanes-Terán I, Jara-Samaniego J, Idrovo-Novillo J, Bustamante MA, Pérez-Murcia MD, Pérez-Espinosa A, López M, Paredes C (2017) Agroindustrial compost as a peat alternative in the horticultural industry of Ecuador. Journal of Environmental management 186(1):79-87. DOI: https://dx.doi.org/10.1016/j.jenvman.2016.10.045

Kaudal BB, Chen D, Madhavan DB, Downie A, Weatherley A (2016) An examination of physical and chemical properties of urban biochar for use as growing media substrate. Biomass and Bioenergy 84:49-58. DOI: https://dx.doi.org/10.1016/j.biombioe.2015.11.012

Kratz D, Nogueira AC, Wendling I, Souza PVD (2015) Substratos renováveis para produção de mudas de Mimosa scabrella. Floresta 45(2):393-408. DOI: http://dx.doi.org/10.5380/rf.v45i2.31249 
Kratz D, Wendling I (2013) Produção de mudas de Eucalyptus dunnii em substratos renováveis. Floresta 43(1):125-136. DOI: http://dx.doi.org/10.5380/rf.v43i1.25989

Lorin HEF, Costa MSSM, Costa LAM, Pereira DC, Carneiro LJ (2016) Stabilization of confined beef cattle manure: characteristics of produced fertilizers. Engenharia Agrícola 36(5):877-885. DOI: https://dx.doi.org/10.1590/1809-4430Eng.Agric.v36n5p877-885/2016

Maguire JD (1962) Speed of germination: Aid in selection and evaluation for seedling emergence and vigor. Crop Science 2(2):176-177.

Malavolta E, Vitti GC, Oliveira AS (1997) Avaliação do estado nutricional das plantas: princípios e aplicações. Piracicaba, POTAFOS, 2 ed. 319 p.

Méndez A, Paz-Ferreiro J, Gil E, Gascó G (2015) The effect of paper sludge and biochar addition on brown peat and coir based growing media properties. Scientia Horticulturae 193:225-230. DOI:

https://dx.doi.org/10.1016/j.scienta.2015.07.032

Menezes Júnior FOG, Fernandes HS, Mauch CR, Silva JB (2000) Caracterização de diferentes substratos e seu desempenho na produção de mudas de alface em ambiente protegido. Horticultura Brasileira 18(3):164-170. DOI: https://dx.doi.org/10.1590/S0102-05362000000300004

Meng X, Dai J, Zhang Y, Wang X, Zhu W, Yuan X, Yuan H, Cui Z (2018) Composted biogas residue and spent mushroom substrate as a growth medium for tomato and pepper seedlings. Journal of Environmental Management 216:62-69. DOI: https://dx.doi.org/10.1016/j.jenvman.2017.09.056
Milori DMBP, Galeti HVA, Martin-Neto L, Dieckow J, González-Pérez M, Bayer C, Salton J (2006) Organic Matter Study of Whole Soil Samples Using Laser-Induced Fluorescence Spectroscopy. Soil Science Society of America Journal 70(1):57-63. DOI: https://dx.doi.org/10.2136/sssaj2004.0270

Moraes PLD, Dias NS, Oliveira AM, Sousa Neto ON, Sarmento JDA, Gonzaga MIS (2018) Effects of nutrient solution salinity on the physiological performance of melon cultivated in coconut fiber. Revista Caatinga 31(3):713-718. DOI: https://dx.doi.org/10.1590/1983$21252018 \mathrm{v} 31 \mathrm{n} 321 \mathrm{rc}$

Nieto A, Gascóa G, Paz-Ferreiro J, Fernández JM, Plaza C, Méndez A (2016) The effect of pruning waste and biochar addition on brown peat based growing media properties. Scientia Horticulturae 199:142-148. DOI: https://dx.doi.org/10.1016/j.scienta.2015.12.012

Santos FT, Ludwig F, Costa LAM, Costa MSSM (2015) Nutrition and growth of potted gerbera according to mineral and organic fertilizer. Ornamental Horticulture 21(2):251258. DOI: https://dx.doi.org/10.14295/aohl.v21i2.750

Spiassi A, Santos FT, Nobrega LHP, Cestonaro T, Costa MSSM (2015) Toxicity of biofertilizers on seeds of lettuce and maize. Científica 43(2):156-164. DOI: http://dx.doi.org/10.15361/1984-5529.2015v43n2p156-164

Stahel WR (2016) The Circular economy. Nature 531:435438. DOI: http://dx.doi.org/10.1038/531435a

Tian Y, Sun X, Li S, Wang H, Wang L, Cao J, Zhang L (2012) Biochar made from green waste as peat substitute in growth media for Calathea rotundifola cv. Fasciata. Scientia Horticulturae 143:15-18. DOI: https://dx.doi.org/10.1016/j.scienta.2012.05.018 